\title{
SYPHILIS MIMICKING AUTOIMMUNE RHEUMATIC DISEASE
}

GERMANA RIBEIRO ARAUJO CARNEIRO DE LUCENA (UNIVERSIDADE FEDERAL DE SÃO PAULO, SÃO PAULO , SP, Brasil), PRISCILA DIAS CARDOSO RIBEIRO (UNIVERSIDADE FEDERAL DE SÃO PAULO, SÃO PAULO, SP, Brasil), DANIEL VIANA DA SILVA E SILVA (UNIVERSIDADE FEDERAL DE SÃO PAULO, SÃO PAULO , SP, Brasil), RENAN RODRIGUES NEVES RIBEIRO DO NASCIMENTO (UNIVERSIDADE FEDERAL DE SÃO PAULO, SÃO PAULO , SP, Brasil), IGOR BELTRÃO DUARTE FERNANDES (UNIVERSIDADE FEDERAL DE SÃO PAULO, SÃO PAULO , SP, Brasil), MARIANA DAVIM FERREIRA GOMES (UNIVERSIDADE FEDERAL DE SÃO PAULO, SÃO PAULO , SP, Brasil), LUÍZA SÁ E RÊGO TUPINAMBÁ (UNIVERSIDADE FEDERAL DE SÃO PAULO , SÃO PAULO , SP, Brasil), RAQUEL MITIE KANNO (UNIVERSIDADE FEDERAL DE SÃO PAULO, SÃO PAULO, SP, Brasil), ALEXANDRE LIMA MATOS (UNIVERSIDADE FEDERAL DE SÃO PAULO, SÃO PAULO, SP, Brasil), EDGARD TORRES DOS REIS NETO (UNIVERSIDADE FEDERAL DE SÃO PAULO, SÃO PAULO, SP, Brasil)

\section{BACKGROUND}

Syphilis is an infectious disease caused by Treponema pallidum, with an incidence of 12 million a year. Secondary syphilis results from the hematogenous spread of the infection, usually 2-12 weeks after the primary infection, and it could affect any organ. Musculoskeletal manifestations may occur at any stage of the disease, except in the primary stage, and also it could mimic a wide variety of rheumatic diseases. Ocular manifestations present a prevalence of $5-10 \%$ in the secondary form, being uveitis the most common form, although it can affect any structure of the eye.s.

\section{CASE REPORT}

A female, 48 years old and caucasian. A previously healthy patient reports holocronial headache since january of 2019, with predominance in the occipital region, character in pressure, moderate intensity. After 45 days, it evolved with edema and arthralgia in the ankles, knees, wrists, proximal inferfalangenas and metacarpophalangeal, associated with morning stiffness less than 15 minutes. After a week, there were onset of erythematous papules, initially pruritic papules, in the distal medial region of the left lower limb, with progression to palms and plants. Fifteen days passed and the lesions evolved to papules and erythematous, non-pruritic or painful plaques disseminated in the trunk and limbs. In April of 2019, it refers to the appearance of scintillating scotomas progressing to a darkened visual area, worse on the right eye, and a bilateral, symmetrical visual turbidity. Then, in May 2019, she was referred to the ophthalmological emergency room, where she was diagnosed with bilateral panuveitis, vitreitis and bilateral retinal vasculitis with bilaterally papilla blotting. On the physical examination, she presented arthritis in the ankles, knees, wrists, proximal inferfalangenas and metacarpofalangeanas. Positive laboratory tests included rheumatoid factor superior to 1:640; anti-nuclear antibody 1:320 fine dotted nuclear, VDRL 1:128 and treponemal reagent assay. Serology for HIV was negative. The analysis showed that CSF had an increase in protein concentration and pleyocitosis. As a result, she was diagnosed with secondary syphilis with neurosyphilis, ophthalmologic involvement and reactional arthritis. Initiated treatment with penicillin $\mathrm{G}$, evolving with clinical improvement.is[i]?

\section{CONCLUSION}

Secondary syphilis could mimic several rheumatic diseases, including systemic lupus erythematosus, rheumatoid arthritis and vasculitis. Arthralgias, myalgias and bone pain might occur in $5-10 \%$ of cases, on the other hand, arthritis in 4-8\%. This disease should always be remembered in a differential diagnosis of patients with polyarthritis, associated with cutaneous and ophthalmologic involvement. 